\title{
Cyanotic Body
}

National Cancer Institute

\section{Source}

National Cancer Institute. Cyanotic Body. NCI Thesaurus. Code C87065.

Blue- or purplish-colored body; this is caused by excessive amounts of deoxygenated hemoglobin in the skin vessels of the body. 